\title{
Phytoplankton pigments in macrozooplankton feces: variability in carotenoid alterations
}

\author{
James R. Nelson* \\ Institute of Marine Resources A-018, Scripps Institute of Oceanography, University of California, San Diego La Jolla, \\ California 92093, USA
}

\begin{abstract}
Phytoplankton pigments and their alteration products in macrozooplankton feces were characterized by high-performance liquid chromatography. Fecal material was obtained from animals collected in the Southern California Bight, USA. Different patterns of fecal pigment composition were observed for 2 size classes of macrozooplankton grazers. Fecal material produced by copepoddominated assemblages contained intact phytoplankton carotenoids. Feces produced by 3 relatively large grazers (2 salp species and a pelagic crab) contained polar carotenoid products, tentatively identified as the ester hydrolysis products of peridinin, fucoxanthin, and $19^{\prime}$-hexanoyloxyfucoxanthin (characteristic carotenoids of major phytoplankton taxa). Degradation of chlorophyll a apparently occurred within the guts of both size classes of macrozooplankton, although some intact chlorophyll a was found in all fecal pellet collections. It is proposed that the difference in carotenoid alterations mediated by the 2 size classes of macrozooplankton grazers is related to differences in gut esterases and to the transit time of ingested material through the guts of the animals. Hydrolysis products of the estersubstituted carotenoids could provide a pigment 'signal' indicating the presence of feces produced by large macrozooplankton grazers in sediment trap collections.
\end{abstract}

\section{INTRODUCTION}

Macrozooplankton can play a significant role in the transport of organic material produced by phytoplankton in the euphotic zone to the deeper water column and the sediments (reviewed in Fowler \& Knauer 1986). Individual phytoplankton normally sink at very slow rates (Eppley et al. 1967, Smayda 1970, Bienfang 1981). As a result of macrozooplankton grazing, organic matter from phytoplankton is repackaged into larger and faster-sinking fecal particles (Small et al. 1979). Phytoplankton pigments and their degradation products can indicate the presence of organic matter derived from the primary producers in sedimenting particles and sediments. Derivatives of phytoplankton pigments have long been utilized as 'biomarkers' by organic geochemists (e.g. Treibs 1936).

Along with chlorophyll $a$, the photosynthetic membranes of phytoplankton contain a variable complement of accessory pigments. These include other chlorophylls $\left(b, c_{1}\right.$, and $\left.c_{2}\right)$, carotenoids, and biliproteins. Certain of the accessory pigments are charac-

\footnotetext{
- Present address: Skidaway Institute of Oceanography, PO Box 13687 Savannah, Georgia 31416, USA
}

teristic of different classes of phytoplankton (see reviews by Goodwin 1971, Jeffrey 1980). Taxonomically diagnostic pigments, such as the major xanthophylls (oxygen-substituted carotenoids), can therefore indicate the relative abundances of specific classes of phytoplankton in the euphotic zone (see e.g. Hallegraeff 1981, Gieskes \& Kraay 1986), and could serve as tracers of organic matter derived from these taxa in particles collected from the deeper water column. Determining what, if any, modification of phytoplankton pigments occurs in the guts of grazers is necessary for understanding their transformations within the water column, and for interpreting the pigment composition of particles collected by sediment traps.

Repeta \& Gagosian $(1982,1984)$ characterized the water column transformations of fucoxanthin, the major carotenoid of diatoms, chrysophytes, and some prymnesiophytes. They concluded that fucoxanthin was degraded to fucoxanthinol within the guts of zooplankton by an enzymatic hydrolysis (converting the 3 '-acetate of fucoxanthin to the 3'-hydroxyl of fucoxanthinol), and suggested that other ester-substituted carotenoids might be similarly degraded. Such carotenoids include peridinin, found in the photosynthetic dinoflagellates (Johansen et al. 1974), and 
$19^{\prime}$-hexanoyloxyfucoxanthin, the major carotenoid of the cosmopolitan coccolithophorid Emiliania huxleyi (Arpin et al. 1976) and several other prymnesiophytes (Gieskes \& Kraay 1986, Wright \& Jeffrey 1987). 19'hexanoyloxyfucoxanthin also contains a second ester linkage at the 19'-position. Repeta \& Gagosian (1984) tentatively identified peridininol in sediment trap samples from Peruvian coastal waters.

Data presented by Repeta (1982) and Repeta \& Gagosian (1984) suggests that the conversion of fucoxanthin to fucoxanthinol may vary with the composition of the macrozooplankton community. This question is addressed in the present study.

This study considers the fate of peridinin, fucoxanthin, and 19'-hexanoyloxyfucoxanthin ingested by macrozooplankton grazers, and particularly, whether ester hydrolysis products of these xanthophylls are formed in the guts of the animals. Comparisons are made between pigments in filtered water samples taken in the euphotic zone and pigments contained in fecal material produced by 2 size classes of macrozooplankton: (1) mixed assemblages dominated by calanoid copepods; (2) larger filter-feeders (2 salp species and a pelagic galatheid crab). These results indicate that the ester-substituted carotenoids were extensively altered only in the guts of the larger grazers, and that their degradation may vary with the concentration of food available to the animals.

\section{METHODS}

Station locations. Field work was conducted within the Southern California Bight, USA. Cruise dates and stations occupied are listed in Table 1. Station locations

Table 1. Stations occupied during cruises (see Fig. 1 for station locations)

\begin{tabular}{cll|}
\hline Cruise & \multicolumn{1}{c}{ Dates } & Stations sampled \\
\hline SCBS-22 & 17-25 May 1983 & San Pedro Channel \\
SCBS-23 & $8-15$ May 1985 & 202, 205 \\
SCBS-24 & $7-16$ Oct 1985 & 202, 205 \\
& 304, 305 \\
22 May 1985 & SIO Pier \\
\hline
\end{tabular}

are shown in Fig. 1. With the exception of Cruise SCBS22 , stations were among those that have been sampled by the Food Chain Research Group since 1974 as part of the Southern Californja Bight Study (SCBS). During Cruise SCBS-22, samples were collected in the San Pedro Channel as the ship followed a drifting sediment trap array (see Nelson et al. 1987).

Sampling procedures. Suspended particles: Water

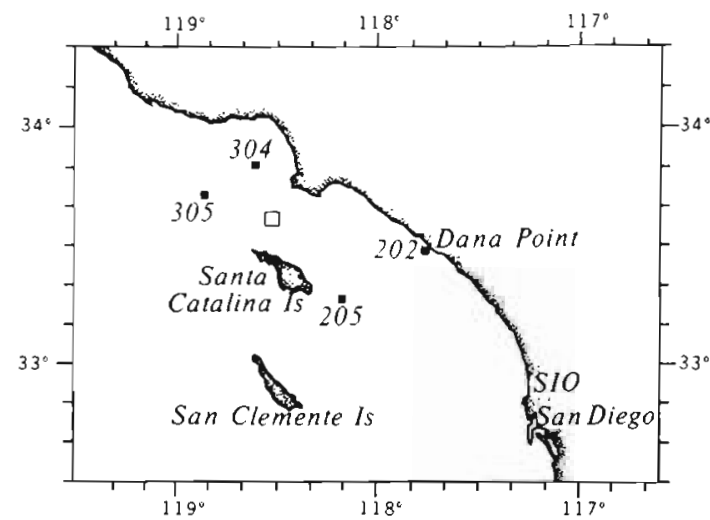

Fig. 1. Location of field stations; numbered stations are among those occupied by the Food Chain Research Group (SCBS study); the open square is the general area sampled during Cruise SCBS-22 (see text); 'SIO': Scripps Institution of Oceanography pier

samples were collected with either $30 \mathrm{l}$ Niskin bottles hung on the hydrographic wire, or in 51 Niskin bottles deployed on a rosette. Samples were screened through $183 \mu \mathrm{m}$ Nitex screen and filtered onto $47 \mathrm{~mm}$ glassfiber filters (Whatman GF/C for Cruise SCBS-22, GF/F for subsequent cruises). Filters were stored frozen $\left(-20^{\circ} \mathrm{C}\right)$ under $\mathrm{N}_{2}$ until analysed. On cruises subsequent to SCBS-22, the filters were quick frozen on dry ice prior to storage in a chest freezer. The pigments in frozen samples were found to be stable for at least 2 mo (Nelson 1986). Durng Cruise SCBS-24, suspended particles from the mixed layer and from the approximate depth of the chlorophyll a maximum were partitioned into 4 size-fractions prior to filtration onto GF/F filters: (1) without prefiltration; (2) prefiltered through $10 \mu \mathrm{m}$ Nitex screen; (3) prefiltered through $5 \mu \mathrm{m}$ Nuclepore filters (polycarbonate); (4) prefiltered through $3 \mu \mathrm{m}$ Nuclepore filters.

Zooplankton fecal material: Animals were collected in the evening $(19: 00$ to $21: 00 \mathrm{~h})$ by oblique net tows through the euphotic zone (as defined by the depth of $1 \%$ of surface irradiance in profiles made during daylight hours). The nets were either $1 \mathrm{~m}$ diameter with $505 \mu \mathrm{m}$ mesh or $0.75 \mathrm{~m}$ diameter with $303 \mu \mathrm{m}$ mesh, and were fitted with non-filtering cod ends. On Cruise SCBS-22, the captured animals were transferred to clean plastic buckets and held in the dark for 1.5 to $3.0 \mathrm{~h}$ to allow egestion and settling of fecal material. Calanoid copepods examined under a dissecting scope after this period appeared to have cleared their guts. The accumulated material was siphoned off, screened through Nitex mesh to eliminate animals (same mesh size as the net), filtered onto glass fiber filters, and stored frozen under $\mathrm{N}_{2}$. On later cruises, the smaller macrozooplankton (predominantly calanoid copepods) were placed in short, conical microzooplankton nets (53 um mesh, designed for use with a large volume 
pumping system) which were suspended in clean plastic containers filled with surface seawater (ca 2001 ). The cod ends of the nets were replaced with glass jars covered by Nitex screen of the same mesh size as the net used to collect the animals. The suspended microzooplankton nets provided the animals with a larger volume enclosure and concentrated the egested fecal material into the cod end jar. The jars were removed after 1.5 to $3.0 \mathrm{~h}$ and the contents $(<500$ $\mathrm{ml})$ were filtered onto glass fiber filters and stored frozen under $\mathrm{N}_{2}$. Examination of the accumulated material under a dissecting scope showed that pellets dominated the mixed assemblage collections when copepods were abundant in the catch. Other amorphous organic particles were also observed, along with some small zooplankton that passed the cod end screen (e.g. copepod naupliar stages).

Large filter-feeding grazers, a pelagic galatheid crab (Pleuroncodes planipes) and two salp species (Cyclosalpa bakeri, and Salpa sp., tentatively S. maxima) were captured on several occasions. These animals were separated from smaller zooplankton and placed in clean buckets filled with surface seawater or filtered seawater. Aggregate (oozoid) and solitary (gonozoid) stages of the salps were not separated. Individual fecal particles were collected with a pipette, rinsed in filtered seawater, pooled, filtered, and stored frozen as described above.

SIO pier samples: In May of 1985, a red water bloom of a dinoflagellate, Prorocentrum micans, occurred in the nearshore waters off San Diego. Surface bucket samples were collected from the Scripps Institution of Oceanography (SIO) pier, filtered, and stored frozen as described above. Several red crabs Pleuroncodes planipes were collected from the SIO pier at the peak of the bloom. The crabs were placed in a constant temperature room $\left(19^{\circ} \mathrm{C}\right)$ in buckets filled with surface water from the bloom, and fecal material that accumulated over a $12 \mathrm{~h}$ period was collected and frozen under $\mathrm{N}_{2}$.

Pigment analysis by HPLC. Pigments were extracted from the frozen filters in $90 \%$ acetone or methanol:acetone $(1: 1)$ with grinding $\left(4^{\circ} \mathrm{C}\right.$, under dim light). Extraction times $\left(-20^{\circ} \mathrm{C}\right)$ lasted as long as overnight in $90 \%$ acetone, but were limited to $3 \mathrm{~h}$ with methanol:acetone. Pigment extracts were concentrated prior to analysis using reversed-phase sample preparation cartridges (C-18), either Rainin 'SPICE' cartridges (Cruise SCBS-22) or Baker 'SPE' columns (all other analyses). Extracts were cleared by filtration, placed in an ice bath to chill, combined with distilled water $\left(4^{\circ} \mathrm{C}\right)$ to bring the extract to $50 \%$ water (if an acetone extract) or $40 \%$ water (if a methanol:acetone extract), then passed through the cartridges (preconditioned by passage of $3.0 \mathrm{ml}$ methanol, followed by $3.0 \mathrm{ml}$ of the appropriate water/solvent mixture). Pigments were eluted from the cartridge with $1.0 \mathrm{ml}$ of $100 \%$ acetone, followed by 2 rinses of $0.5 \mathrm{ml} 100 \%$ acetone. The acetone volume was then reduced to $1.0 \mathrm{ml}$ under a stream of $\mathrm{N}_{2}$. For extracts of cultured phytoplankton, recovery of the major xanthophylls and chlorophylls a and $b$ after concentration on the solid phase cartridges averaged $92 \%$, with an average coefficient of variation of $6.8 \%$ for recovery of individual pigments from triplicate samples. Recovery of the nonpolar carotenes and the most polar pigments (chlorophyllide $a$ and chlorophylls $c_{1}+c_{2}$ ) was less than $90 \%$ and more variable. Quantitative results for those pigments are not presented. The recovery efficiency for relatively polar xanthophyll alteration products (below) was not established, but was likely to be similar to that of the other polar pigments.

High performance liquid chromatography (HPLC) analysis followed the method of Mantoura \& Llewellyn (1983) with minor modifications. A linear gradient was run at $5 \% \mathrm{~min}^{-1}$ from methanol: $\mathrm{H}_{2} \mathrm{O}$ : modified $\mathrm{P}$ ' $(80: 10: 10)$ to methanol:acetone $(80: 20)$. After $5 \mathrm{~min}$, a second linear gradient was run at $10 \% \mathrm{~min}^{-1}$ to methanol:acetone $(60: 40)$. The flow rate was maintained at $1.0 \mathrm{ml} \mathrm{min}^{-1}$. The modified ion-pairing reagent solution ('modified $\mathrm{P}^{\prime}$ ) consisted of an aqueous solution of $50 \mu \mathrm{M}$ tetrabutylammonium acetate (Fluka) and $250 \mu M$ ammonium acetate buffer, the latter being $1 / 4$ the concentration used by Mantoura \& Llewellyn (1983) to reduce the initial back pressure in the system. Organic solvents were HPLC grade and water came from either a Corning still or a Milli-Q (Millipore Corp.) water purification system.

The chromatographic system consisted of a Tracor Model 980A gradient mixer, a Spectra-Physics Model SP8770 HPLC pump, Valco injection valve $(100$ or $250 \mu \mathrm{l}$ injection volume), and a Waters 'Nova-Pak' column $(4 \mu \mathrm{m}$ spherical C-18 packing, $15 \mathrm{~cm}$ length $\times$ $3.9 \mathrm{~mm}$ diameter). Sample detection was by absorbance at $436 \mathrm{~nm}$ (Spectra-Physics Model 8200 detector). Chromatograms were recorded and peak areas were integrated with a Hewlett-Packard 3390A integrator. For some of the later analyses, a fluorescence detector (Fluoromonitor III, Laboratory Data Control), equipped with a blue lamp (F4T5/B) and Corning filters 5-60 (excitation) and 2-64 (emission), was added in series with the absorbance detector for improved detection of the chlorophylis and their derivatives. The output signal from the fluorescence detector was not calibrated for the present study.

This HPLC system does not separate the dihydroxy carotenoids zeaxanthin and lutein, nor chlorophylls $c_{1}$ and $c_{2}$ (Nelson 1986). The chromatographic peaks for these pigments (potentially mixtures) will be referred to as zeaxanthin/lutein and chlorophyll $c$ in the results presented below. 
Calibration curves for pigments detected by visible absorbance (436 nm) were constructed from injections of stock solutions and were linear in each case. Chlorophyll a was obtained from Sigma. Other pigments were isolated by thin-layer chromatography (TLC) from extracts of cultured phytoplankton: chlorophyll $b$ and lutein from Chlorella (FCRG clone Chlorella sp.); fucoxanthin from Skeletonema costatum (FCRG clone Skele); peridinin and diadinoxanthin from Amphidinium carterae (PY-32, = Plymouth 450); $19^{\prime}$-hexanoyloxyfucoxanthin from Emiliania huxleyi (BT-6); zeaxanthin from Synechococcus sp. (DC-2). Chlorophylls were isolated on cellulose developed in one dimension with $2.0 \% n$-propanol in ligroine (based upon the method of Jeffrey 1974, 1981). Carotenoids were isolated on silica as in Johansen et al. (1974) with the mobile phase varied from 30 to $50 \%$ acetone in hexane depending on the mobility of the pigment and its apparent degree of purification. Concentrations of stock solutions in appropriate solvents were calculated using extinction coefficients from the literature: chlorophylls $a$ and $b(90 \%$ acetone) from Jeffrey \& Humphrey (1975); peridinin and diadinoxanthin (100\% acetone) from Johansen et al. (1974); zeaxanthin and lutein (ethanol) from Davies (1976); fucoxanthin (100\% acetone) from Jensen (1973); and 19' -hexanoyloxyfucoxanthin from the extinction coefficient for fucoxanthin, corrected for the difference in molecular weight (Haxo 1985)

Retention times for individual pigments varied between some sets of samples. Several factors may have contributed to this, including temperature effects, differences in solvent composition, variability in gradient formation, and column aging. However, relative retention times of peaks within a limited elution range appeared to be consistent. Positions of uncalibrated or unknown peaks were referenced to the retention times of known peaks (extracts of cultured phytoplankton) for comparisons between sample sets.

Tentative identifications of carotenoid and chlorophyll degradation products. Tentative assignments for several unknown pigments separated by HPLC were made on the basis of the following lines of evidence. First, for samples analysed by both visible absorbance and fluorescence detection, unknown products could be designated as carotenoids (non-fluorescing) or derivatives of the chlorophylls (fluorescing). Second, where sufficient material was available, peaks eluting from the analytical column were manually collected, and fractions from several HPLC separations were pooled to obtain at least $1 \mathrm{ml}$ of pigment solution. Visible absorption spectra were determined in lowvolume $1 \mathrm{~cm}$ cuvettes in the eluting solvent mixture, and, in some cases, again after the pigments were transferred to other solvents. These spectra were com- pared to literature reports. Third, the retention times of unknown peaks were compared to the retention times for products obtained by laboratory modification of the parent compounds. Methanol solutions of peridinin, fucoxanthin, and 19'-hexanoyloxyfucoxanthin (isolated by TLC) were subjected to alkaline hydrolysis following the procedures of Johansen et al. (1974). The reaction product mixtures were separated by HPLC and visible absorption spectra of individual peaks (manually collected as above) were recorded and compared to published spectra.

\section{RESULTS}

To emphasize the differences in pigment composition found between various samples, the results of pigment analyses will be grouped as follows: (1) suspended particles collected within the euphotic zone (phytoplankton and fine detritus); (2) the fecal material of smaller macrozooplankton; (3) the fecal material of larger grazers. A visual display of the pigment composition of various samples is provided by examples of HPLC chromatograms.

\section{Pigments in suspended particles from the euphotic} zone

A pronounced cross-shelf gradient in the standing crop of phytoplankton is often found within the Southern California Bight (Eppley et al. 1978). Stn 202, located north of Dana Point at about mid-shelf (Fig. 1), is representative of inshore conditions, typically with relatively high phytoplankton biomass. Stn 205 is representative of an offshore station within the Bight, with low phytoplankton biomass in the surface mixed layer, and distinct subsurface maxima in the vertical concentration profiles of chlorophyll $a$ and particulate organic carbon (see Eppley et al. 1977)

Vertical concentration profiles of phytoplankton pigments from Stns 202 and 205 (Cruise SCBS-23) are illustrated in Fig. 2. Fucoxanthin was the dominant xanthophyll at the inshore Stn 202 at all depths. At the offshore Stn 205, the pronounced pigment maximum contained roughly equal concentrations of peridinin. fucoxanthin, and 19'-hexanoyloxyfucoxanthin, indicating a mixed phytoplankton assemblage.

Size-fractioned pigment samples taken on Cruise SCBS-24 from Stns 202 and 205 are listed in Table 2. Since the results of size-fractioned analyses can be influenced by cell breakage, irregular cell dimensions, and passage of flexible cells through the pores of filters, these results must be interpreted with some caution. The data in Table 2 show some inconsistencies. Also, 

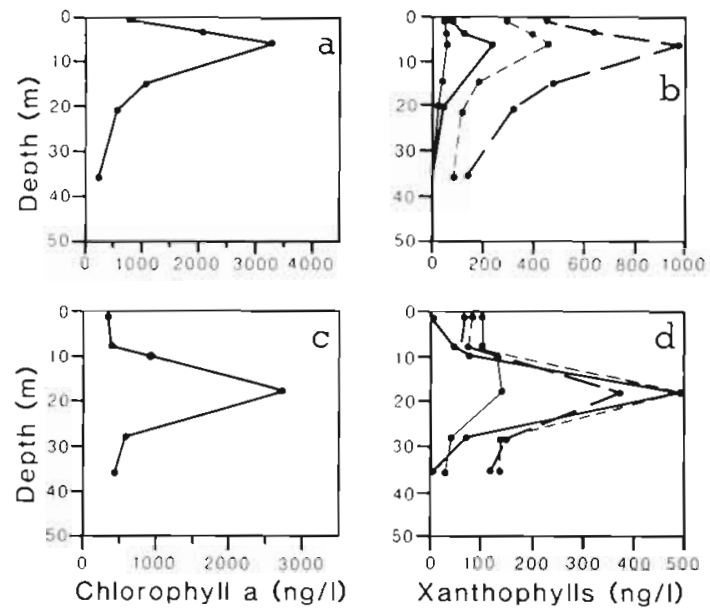

Fig. 2. Vertical concentration profiles of phytoplankton pigments from Cruise SCBS-23: (a, b) Stn 202; (c, d) Stn 205. For xanthophyll profiles (b, d): solid heavy line, 19'-hexanoyloxyfucoxanthin; broken heavy line, fucoxanthin; light solid line, zeaxanthin; light broken line, peridinin

only 2 depths were sampled. With these limitations in mind, the data indicate that the phytoplankton assemblage was predominantly small cells at the offshore Stn
205 (most $<3 \mu \mathrm{m}$ in the surface layer and many $<5 \mu \mathrm{m}$ at the chlorophyll maximum). At the inshore Stn 202, a larger proportion of the phytoplankton biomass was found in the larger size fractions ( $>10 \mu \mathrm{m}$ and $>5 \mu \mathrm{m}$ ). At both stations, most of the chlorophyll $b$ and zeaxanthin/lutein passed the $5 \mu \mathrm{m}$ filters and often the $3 \mu \mathrm{m}$ filters, indicating that these pigments were predominantly from picoplanktonic chlorophytes, prasinophytes and/or cyanobacteria. Size-fractioned pigment samples for other stations from Cruise SCBS-24 are reported in Nelson (1986).

\section{Pigments in fecal material of smaller macrozooplankton}

The macrozooplankton assemblage at Stn 202 was dominated by calanoid copepods during Cruises SCBS23 and SCBS-24 (Table 3). Fig. 3a, b compares HPLC chromatograms for suspended particles from the chlorophyll a maximum $(10 \mathrm{~m})$ and fecal material from the mixed zooplankton assemblage (samples from Cruise SCBS-23). A fecal pigment chromatogram from a

Table 2. Size-fractioned pigment samples (Cruise SCBS-24). 'Whole water' concentrations are from the pigments retained on GF/ F filters without prefiltration. Pigments: Perid = peridinin; Fucox $=$ fucoxanthin; $19{ }^{\prime}$-Fucox $=19^{\prime}$-hexanoyloxyfucoxanthin; Zeax $=$ zeaxanthin + lutein; $\mathrm{Chl} b=$ chlorophyll $b$; Chl $a=$ chlorophyll $a$; nd = not detected

\begin{tabular}{|c|c|c|c|c|c|c|}
\hline \multirow[t]{2}{*}{ Station } & \multirow[t]{2}{*}{$\begin{array}{l}\text { Depth } \\
\text { (m) }\end{array}$} & \multirow[t]{2}{*}{ Pigment } & \multirow[t]{2}{*}{$\begin{array}{l}\text { Concentration } \\
\text { whole water } \\
(\mathrm{GF} / \mathrm{F})\left(\mathrm{ng} \mathrm{l}^{-1}\right)\end{array}$} & \multicolumn{3}{|c|}{$\begin{array}{c}\text { Fraction of 'whole water' passing prefilter and } \\
\text { retained on GF/F filter }\end{array}$} \\
\hline & & & & $10 \mu \mathrm{m}$ & $5 \mu \mathrm{m}$ & $3 \mu \mathrm{m}$ \\
\hline \multirow[t]{6}{*}{202} & 1 & Perid & 74.6 & 0.17 & trace & trace \\
\hline & & Fucox & 58.1 & 0.77 & 0.47 & 0.31 \\
\hline & & 19 -Fucox & 55.7 & 0.89 & 0.68 & 0.48 \\
\hline & & Zeax & 56.0 & 0.99 & 0.96 & 0.78 \\
\hline & & Chl $b$ & 40.0 & 1.00 & 0.98 & 0.24 \\
\hline & & Chl a & 293.9 & 0.74 & 0.64 & $(0.08)^{\mathrm{a}}$ \\
\hline \multirow[t]{6}{*}{202} & 24 & Perid & 55.4 & 0.53 & 0.30 & 0.13 \\
\hline & & Fucox & 228.5 & 0.81 & 0.44 & 0.24 \\
\hline & & $19^{\prime}$-Fucox & 223.0 & 0.85 & 0.69 & 0.48 \\
\hline & & Zeax & 40.9 & 0.92 & 0.86 & 0.68 \\
\hline & & Chl $b$ & 185.5 & 1.13 & 0.92 & 0.80 \\
\hline & & Chl a & 547.2 & 1.16 & 0.65 & 0.60 \\
\hline \multirow[t]{6}{*}{205} & 5 & Perid & 9.1 & trace & nd & nd \\
\hline & & Fucox & 19.2 & 0.98 & 0.93 & 0.37 \\
\hline & & $19^{\prime}$-Fucox & 30.3 & 1.01 & 0.72 & 0.42 \\
\hline & & Zeax & 51.4 & 0.96 & 0.98 & 0.85 \\
\hline & & Chl $b$ & 14.8 & 0.92 & 1.04 & 0.94 \\
\hline & & Chl a & 123.9 & 0.83 & 0.83 & 0.78 \\
\hline \multirow[t]{6}{*}{205} & 45 & Perid & 13.3 & 0.41 & nd & 0.26 \\
\hline & & Fucox & 61.3 & 0.83 & 0.79 & 0.33 \\
\hline & & $19^{\prime}$-Fucox & 180.1 & 0.93 & 0.57 & 0.45 \\
\hline & & Zeax & 26.8 & 1.05 & 0.55 & 0.73 \\
\hline & & Chl $b$ & 125.7 & 0.83 & 0.50 & 0.73 \\
\hline & & Chl a & 426.0 & 0.68 & 0.58 & 0.57 \\
\hline
\end{tabular}


Table 3. Qualitative composition of zooplankton captured in net tows for collection of fecal pellets

\begin{tabular}{|ccl|}
\hline Cruise & Station & \multicolumn{1}{c|}{ Zooplankton } \\
\hline SCBS-22 & $\begin{array}{c}\text { San Pedro } \\
\text { Channel }\end{array}$ & $\begin{array}{l}\text { (1) Mixed assemblage, predomi- } \\
\text { nantly calanoid copepods, some } \\
\text { euphausids } \\
\text { (2) Pleuroncodes planipes }\end{array}$ \\
SCBS-23 & 205 & $\begin{array}{l}\text { (1) Mixed assemblage, predomi- } \\
\text { nantly calanoid copepods, fewer } \\
\text { euphausids, amphipods } \\
\text { (2) Salpa sp. } \\
\text { SCBS-24 }\end{array}$ \\
202 & $\begin{array}{l}\text { Predominantiy calanoid cope- } \\
\text { podserer euphausids } \\
\text { Predominantly calanoid cope- } \\
\text { pods } \\
\text { Mixed assemblage of smaller } \\
\text { macrozooplankton } \\
\text { Cyclosalpa bakeri }\end{array}$ \\
& 305 & $\begin{array}{l}\text { Cyclosalpa bakeri } \\
\text { Pleuroncodes planipes }\end{array}$ \\
\hline
\end{tabular}
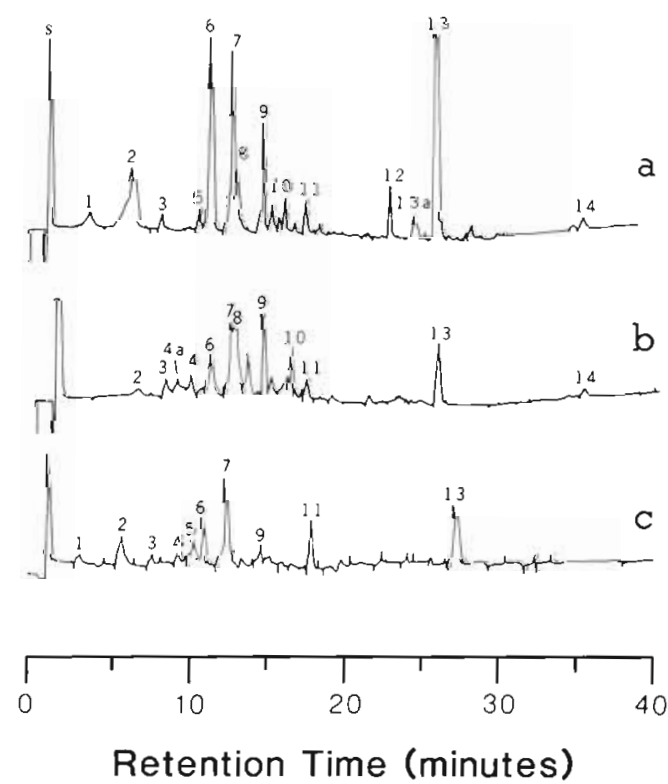

Fig. 3. HPLC chromatograms (absorption at $436 \mathrm{~nm}$ ). Samples: (a) Cruise SCBS-23, Stn 202, suspended particles at $10 \mathrm{~m}_{\text {i (b) }}$ Cruise SCBS-23, Stn 202, fecal pellets from a mixed zooplankton assemblage dominated by calanoid copepods; (c) Cruise SCBS-22, fecal pellets from mixed zooplankton assemblage, calanoid copepods with some euphausids. Peak identifications: s, solvent peak from sample injection; 1 , unidentified, chlorophyll c-like absorption; 2 , chlorophyll $c ; 3$, peridinin; 4 , pheophorbide $a_{i} 4 \mathrm{a}$, possibly pheophorbide $b ; 5$, unidentified, fucoxanthin-like absorption; 6, fucoxanthin; $7,19^{\prime}$-hexanoyloxyfucoxanthin; 8, unidentified, pheophorbide a derivative; 9, diadinoxanthin; 10 , diatoxanthin; 11 , zeaxanthin/lutein; 12 . chlorophyll $b_{i} 13 a$, possibly an allomer of chlorophyll $a_{i} 13$, chlorophyll $a ; 14, \beta$-carotene. Unlabelled peaks were not identified mixed macrozooplankton assemblage collected during Cruise SCBS-22 is illustrated in Fig. 3c. The major carotenoids were present in the fecal samples, and there is no evidence in the chromatograms that peridinin, fucoxanthin, or $19^{\prime}$-hexanoyloxyfucoxanthin were converted to other detectable products. Chlorophyll a was also found in the fecal samples (Fig. 3b. c). Fecal material collected on Cruise SCBS-24 (Stns 202 and 205) from mixed assemblages of smaller macrozooplankton showed a similar pattern of pigment composition, with the carotenoids dominated by the undegraded phytoplankton xanthophylls in each sample (Nelson 1986).

\section{Pigments in fecal material of larger macrozooplankton grazers}

Comparison of HPLC chromatograms for suspended particles from $8 \mathrm{~m}$ (mixed layer; Fig. $4 \mathrm{a}$ ) and suspended particles from $18 \mathrm{~m}$ (the chlorophyll a maximum; Fig.
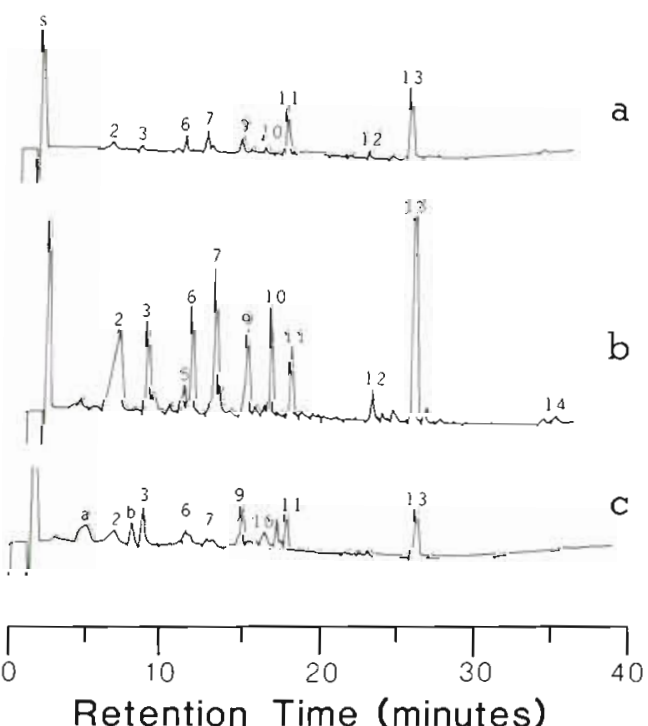

Fig. 4. HPLC chromatograms (absorption at $436 \mathrm{~nm}$ ) for samples collected on Cruise SCBS-23, Stn 205: (a) suspended particles from $8 \mathrm{~m}$ (surface mixed layer); (b) suspended particles from $1.8 \mathrm{~m}$ (chlorophyll a maximum); (c) Salpa sp. feces. Numbered peak identifications as for Fig. 3. Peaks ' $a$ ' and ' $b$ ' are polar products not found in suspended particle samples or

in the feces collected from smaller macrozooplankton

4b) and Salpa sp. feces (Fig. 4c) indicates that the pigment composition of the salp feces was substantially altered from that of the presumed dietary source material (samples from Stn 205, Cruise SCBS-23). Both fucoxanthin and 19'-hexanoyloxyfucoxanthin were present in very low amounts in the salp feces relative to their proportions in the filtered samples from the euphotic zone (Fig. 2d). Also, 2 prominent peaks at the polar end of the fecal pigment chromatogram (peaks 'a' 
and ' $b$ ' in Fig. 4c) were not detected in the filtered water samples (Fig. $4 \mathrm{a}, \mathrm{b}$ ).

HPLC chromatograms for fecal pigments from Salpa sp., and 2 other large grazers, the salp Cyclosalpa bakeri and the pelagic crab Pleuroncodes planipes, are compared in Fig. 5 (collection locations listed in Table 3). C. bakeri fecal pigments were analysed with both fluorescence and absorbance detection (Fig. 5a, b). Little fucoxanthin and $19^{\prime}$-hexanoyloxyfucoxanthin
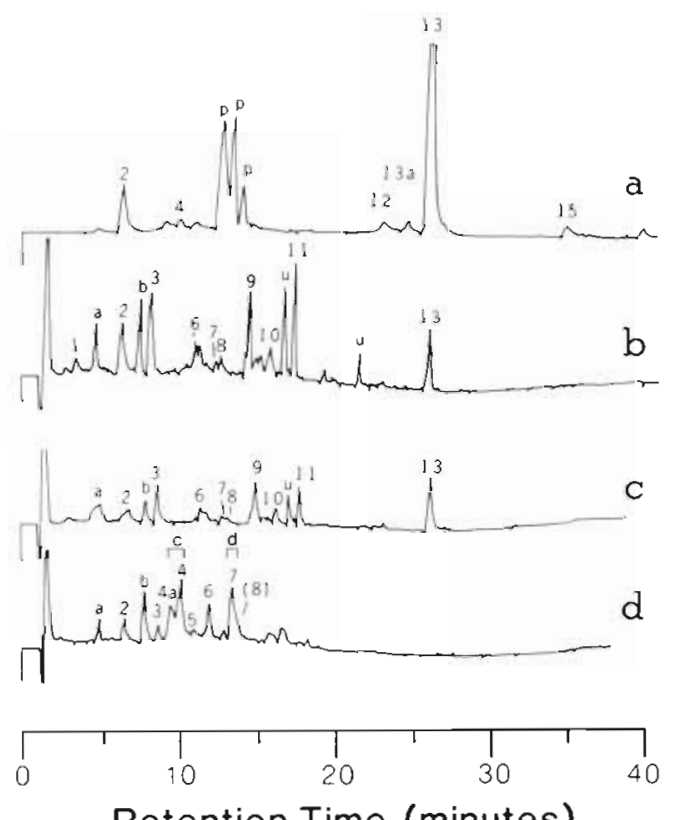

Retention Time (minutes)

Fig. 5. Fecal pigments of large macrozooplankton grazers: (a) fluorescence chromatogram and (b) absorbance chromatogram (436 nm) for Cyclosalpa bakeri feces collected on Cruise SCBS-24; (c) absorbance chromatogram $(436 \mathrm{~nm})$ for Salpa $s p$. feces collected on Cruise SCBS-24; (d) absorbance chromatogram (436 nm) for Pleuroncodes planipes feces collected on Cruise SCBS-22. Numbered peak identifications as for Fig. 3, plus 15, pheophytin $a$. Peaks ' $a$ ' and ' $b$ ' are apparent derivatives of carotenoids. Note the lack of corresponding peaks at these positions in the fluorescence chromatogram (a) Peaks labelled ' $p$ ' in (a) are unidentified pheopigments. Peaks labelled ' $u$ ' are unidentified xanthophylls. In (d), peaks ' $a$ ', ' $b$ ', and the bracketed peaks ' $c$ ' and ' $d$ ' were collected for determination of visible absorption spectra

were detected in the $C$. bakeri feces, and unidentified polar peaks (peaks ' $a$ ' and ' $b$ ') were present that were not found in suspended particles from the euphotic zone (Stn 205, Cruise SCBS-24, see Table 2 for the sizefractioned pigment concentrations). The unidentified polar peaks did not show a fluorescence signal with the detection system employed (Fig. 5a), indicating that they were carotenoids and not derivatives of the chlorophylls. Such polar peaks were also found in Salpa sp. feces collected during Cruise SCBS-23 (Fig. $5 c)$ and $P$. planipes feces collected during Cruise SCBS22 (Fig. 5d). In each case illustrated in Fig. 5, the fecal pigments from the larger grazers showed substantial alteration from the pigments of suspended particles. However, as discussed in the following section, there was one exception to this pattern of fecal pigment composition for the larger grazers.

\section{Pleuroncodes planipes fecal material collected during a dinoflagellate bloom}

A bloom of the dinoflagellate Prorocentrum micans was noted in La Jolla Bay in mid-May of 1985 and lasted until early June 1985. The red water bloom was found throughout the inshore waters of San Diego county and as far south as the Islas Coronados, Mexico (pers. obs.). In La Jolla Bay, the dinoflagellates were often concentrated into pronounced bands roughly parallel to the coast by the late morning hours. At the peak of the bloom, chlorophyll a within concentrated bands exceeded $70 \mathrm{Mg} \mathrm{l}^{-1}$ (Nelson 1986). The feces of Pleuroncodes planipes collected during this period contained predominantly the undegraded phytoplankton pigments (Fig. 6). This contrasts with the $P$. planipes fecal samples collected during Cruise SCBS22 in the San Pedro Channel, where extensive degradation of several xanthophylls had apparently occurred, and chlorophyll a was nearly undetectable (Fig. 5d).
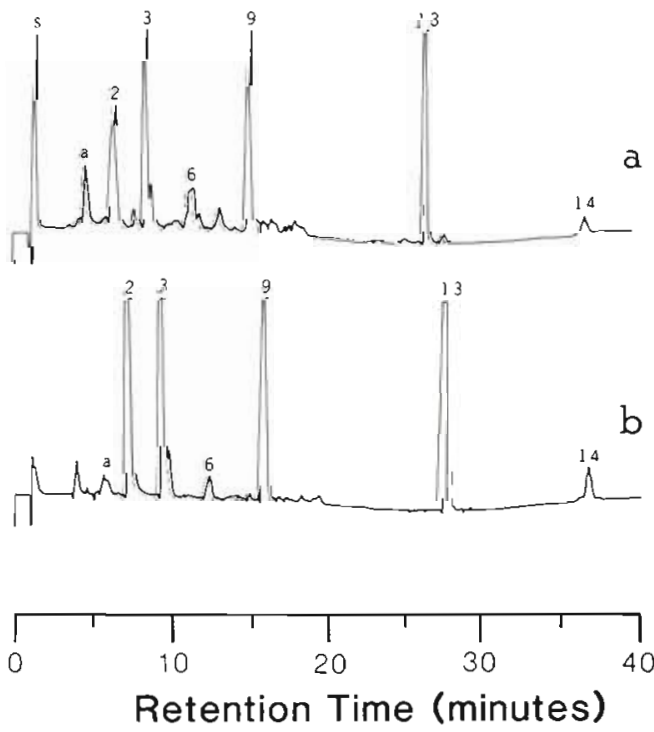

Fig. 6. HPLC chromatograms (absorbance at $436 \mathrm{~nm}$ ) for samples collected from the SIO pier during a dinoflagellate bloom: (a) Pleuroncodes planipes feces; (b) filtered surface water. Numbered peak identifications as for Fig. 3. Peak ' $a$ ' may be a polar carotenoid product. The later retention times for peaks in (b) appears to have been due to the use of a slightly more polar 'A' solvent mixture in the gradient formation (see 'Methods') 
Tentative identification of carotenoid and chlorophyll degradation products

By pooling fractions manually collected from separate analytical HPLC runs, sufficient material was obtained for the determination of the visible absorption spectra for several pigments from Pleuroncodes planipes feces (samples from Cruise SCBS-22). Table 4 lists wavelengths of maximum absorption for collected fractions (labelled ' $a$ ', ' $b$ ', 'c', and ' $d$ ' in Fig. 5d). Absorption spectra for these fractions are illustrated in Fig. 7. For samples with low absorbance values, the spectra have been smoothed by eyefit curves to eliminate instrument noise.

Fractions ' $a$ ' and ' $b$ ' (Fig. 5d) are indicated to be carotenoids by their absorption spectra (Fig. $7 \mathrm{a}, \mathrm{b}$ ) and by the absence of corresponding peaks in fluorescence chromatograms (not illustrated). Peaks at these reten- tion times were also found in the fecal samples from the 2 salp species (Fig. 5b, c). The absorption of fraction ' $b$ ' in the eluting solvent is fucoxanthin-like (Fig. $7 \mathrm{~b}$ ). Moved to $100 \%$ acetone (Fig. $5 \mathrm{c}$ ), the absorption spectrum of fraction ' $b$ ' is quite similar to acetone spectra of fucoxanthin illustrated in the literature (e.g. Wright \& Jeffrey 1987). Fucoxanthin-like absorption and a polar elution position (lower retention time) relative to fucoxanthin are consistent with the characteristics of fucoxanthinol. Conversion of the $3^{\prime}$-acetate of fucoxanthin to the $3^{\prime}$-hydroxyl of fucoxanthinol results in a more polar molecule and does not alter the visible absorption of the molecule (Bonnett et al. 1969, Repeta 1982). The slight differences in the absorption of fucoxanthin in the eluting solvent (Fig. 7d) and fraction ' $b$ ' (Fig. 7b) may result from the change in solvent composition which occurs during the HPLC run.

The less polar fractions ' $c$ ' and 'd' from the crab fecal

Table 4. Absorption maxima of pigment fractions collected from HPLC separations

\begin{tabular}{|c|c|c|c|c|c|}
\hline \multicolumn{6}{|c|}{ A. Pleuroncodes fecal pigments } \\
\hline $\begin{array}{l}\text { Peak label } \\
\text { (Fig. 5d) }\end{array}$ & $\begin{array}{l}\text { Abs. spectrum } \\
\quad \text { (Fig. 7) }\end{array}$ & $\begin{array}{l}\text { Retention } \\
\text { time (min) }\end{array}$ & Solvent & $\begin{array}{l}\text { Abs. maxima } \\
\qquad(\mathrm{nm})\end{array}$ & $\begin{array}{l}\text { Identification } \\
\text { (see text) }\end{array}$ \\
\hline 'a' & $7 a$ & 4.5 & Eluant & $(\sim 451)(\sim 471)$ & Xanthophyll products \\
\hline$b^{\prime}$ & 70 & 7.5 & Eluant & $447,(-469)$ & Fucoxanthinol? \\
\hline 'b' & $7 c$ & 7.5 & $100 \%$ acetone & $(426), 447,472$ & Fucoxanthinol? \\
\hline- & $7 d$ & 11.2 & Eluant & $450,(\sim 466)$ & Fucoxanthin \\
\hline ' $c^{\prime}$ & $7 \mathrm{e}$ & 9.1 & Eluant & 437,656 & Pheophorbides $b, a$ \\
\hline 'd' & $7 \mathrm{f}$ (total) & 12.8 & Eluant & 412,665 & Mixture \\
\hline- & $7 \mathrm{f}$ (difference) & - & - & $446,(\sim 468)$ & \\
\hline \multicolumn{6}{|c|}{ B. Base hydrolysis products of peridinin } \\
\hline \multicolumn{2}{|c|}{$\begin{array}{c}\text { Retention time } \\
\text { (min) }\end{array}$} & Solvent & \multicolumn{2}{|r|}{ Abs. maxima } & $\begin{array}{l}\text { Identification } \\
\quad \text { (see text) }\end{array}$ \\
\hline \multicolumn{2}{|c|}{4.3} & \multicolumn{2}{|l|}{ Eluant } & 473 & Peridininol \\
\hline \multicolumn{2}{|c|}{ a } & \multicolumn{2}{|l|}{$100 \%$ acetone } & 468 & Peridininol \\
\hline \multicolumn{2}{|c|}{7.9} & \multicolumn{2}{|l|}{ Eluant } & 472 & Peridinin \\
\hline & & \multicolumn{2}{|l|}{$100 \%$ acetone } & 466 & Peridinin \\
\hline \multicolumn{6}{|c|}{ a Pigments isolated by thin-layer chromatography } \\
\hline \multicolumn{6}{|c|}{ C. Base hydrolysis products of fucoxanthin } \\
\hline \multicolumn{2}{|c|}{$\begin{array}{c}\text { Retention time } \\
(\text { min) }\end{array}$} & Solvent & \multicolumn{2}{|r|}{ Abs. maxima } & $\begin{array}{l}\text { Tentative identification } \\
\text { (Nelson 1986) }\end{array}$ \\
\hline \multicolumn{2}{|c|}{6.0} & \multicolumn{2}{|l|}{ Eluant } & 462 & Isofucoxanthin? \\
\hline \multicolumn{2}{|c|}{9.6} & \multicolumn{2}{|l|}{ Eluant } & $400,423,450$ & Fucoxanthol? \\
\hline \multicolumn{2}{|c|}{12.6} & \multicolumn{2}{|l|}{ Eluant } & $400,422,449$ & Paracentrol? \\
\hline \multicolumn{6}{|c|}{ D. Base hydrolysis products of $19^{\prime}$-hexanoyloxyfucoxanthin } \\
\hline \multicolumn{2}{|c|}{$\begin{array}{c}\text { Retention time } \\
\text { (min) }\end{array}$} & \multicolumn{2}{|c|}{ Solvent } & Abs. maxima & $\begin{array}{l}\text { Tentative identification } \\
\text { (Nelson 1986) }\end{array}$ \\
\hline \multicolumn{2}{|c|}{4.4} & \multicolumn{2}{|l|}{ Eluant } & $\sim 458$ & $\begin{array}{l}19^{\prime} \text {-hydroxyisofucoxan- } \\
\text { thinol? }\end{array}$ \\
\hline \multicolumn{2}{|c|}{5.1} & \multicolumn{2}{|l|}{ Eluant } & -450 & $19^{\prime}$-hydroxyfucoxanthinol? \\
\hline \multicolumn{2}{|c|}{7.2} & \multicolumn{2}{|l|}{ Eluant } & $400,423,450$ & Fucoxanthol-like product? \\
\hline
\end{tabular}



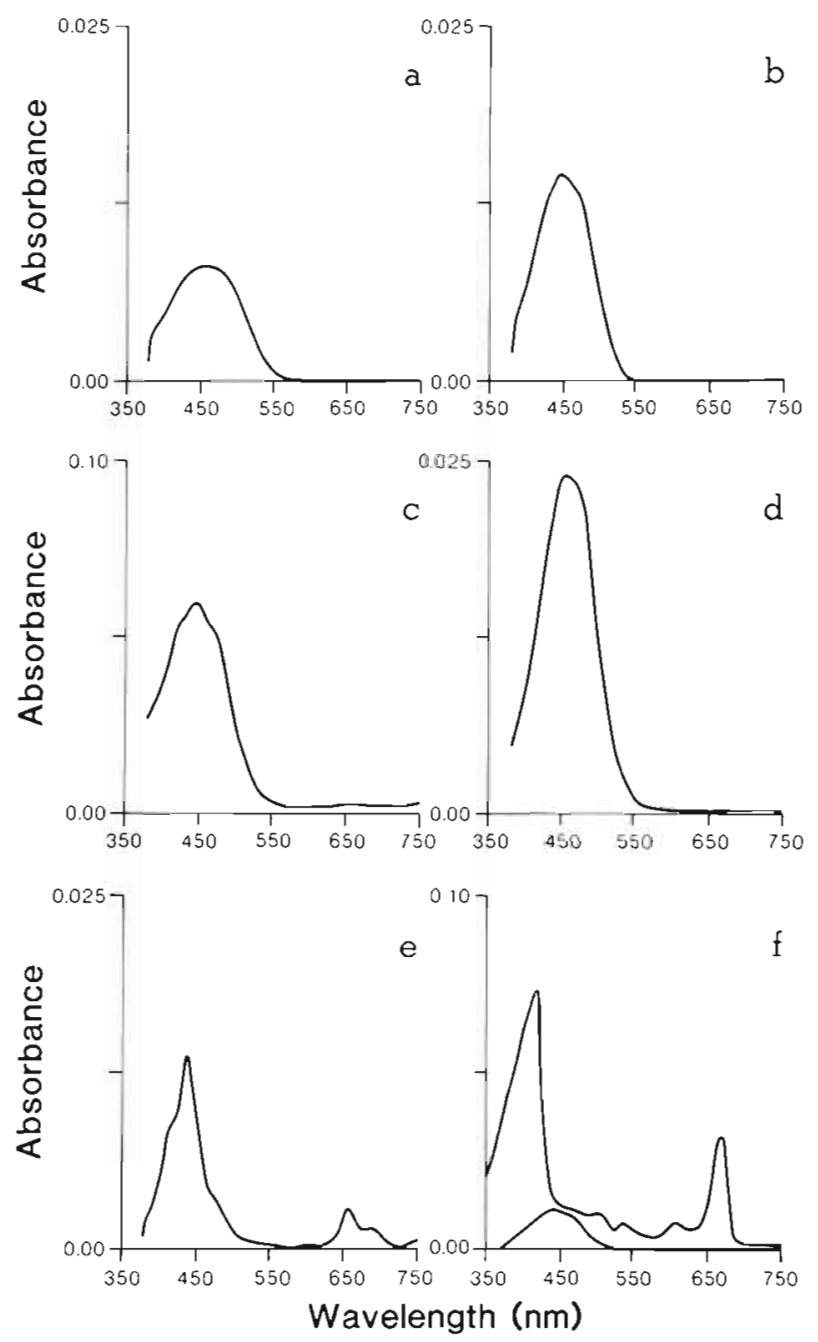

Fig. 7. Visible absorption spectra for pigment fractions separated by HPLC. Wavelengths of maximum absorption are listed in Table 4A. All pigment fractions except (d) are from Pleuroncodes planipes feces collected on Cruise SCBS-22, with peak identifications as in Fig. 5d: (a) fraction ' $a$ ' in the eluting solvent; (b) fraction ' $b$ ' in the eluting solvent; (c) fraction ' $b$ ' moved to $100 \%$ acetone; (d) fucoxanthin in the eluting solvent (sample from stock solution); (e) fraction ' $c$ ' in the eluting solvent; (f) fraction ' $\alpha$ ' in the eluting solvent. The lower spectrum in (f) is a difference spectrum (see text) indicating the estimated absorption contributed by $19^{\prime}$-hexanoyloxyfucoxanthin (peak 7)

sample (Fig. 5d) are mixtures of pigments from poorly resolved peaks. The absorption spectrum of fraction ' $c$ ' (Fig. 7e) indicates that the major pigment was pheophorbide $b$ with a smaller amount of pheophorbide $a$. The absorbance of fraction 'd' (Fig. $7 \mathrm{f}$ upper curve) is similar to that of pheophorbide a. However, pheophorbide a obtained by acidification of chlorophyllide a elutes at a more polar position, and the retention time of fraction ' $d$ ' corresponded to that established for 19'-hexanoyloxyfucoxanthin. A difference spectrum, obtained by subtracting the absorption of pheophorbide a (in $90 \%$ acetone, normalized to the sample absorption at $665 \mathrm{~nm}$ ) from the total absorption spectrum of fraction'd', was fucoxanthin-like (Fig. 7f, lower spectrum). Thus, fraction 'd' may be composed of a mixture of 19' -hexanoyloxyfucoxanthin and a derivative of pheophorbide a. Methyl-substituted derivatives of pheophorbide a (which are less polar than pheophorbide a) have been described in the literature (e.g. Barrett \& Jeffrey 1971) and Vernet \& Lorenzen (1987) reported finding several pheophorbide a-like pigments in field samples of suspended particles and zooplankton fecal pellets analysed by HPLC. It is possible that the pheophorbide derivative is an artifact of sample storage or extraction (see Mantoura \& Llewellyn 1983) rather than a naturally-occurring product.

\section{Base hydrolysis of ester-substituted carotenoids}

The major base hydrolysis products of peridinin eluted at a more polar position (lower retention time) than peridinin (Table 4B). Absorption spectra in 100\% acetone of peridinin and the reaction product (separated by thin-layer chromatography by the procedure of Johansen et al. 1974) showed broad absorption maxima, centered at $466 \mathrm{~nm}$ for peridinin and $468 \mathrm{~nm}$ for its brick-red derivative (Table 4B; Nelson 1986); consistent with the identification of the polar derivative as peridininol. The retention time of peridininol produced by base hydrolysis corresponds to that of peak ' $a$ ' in the Pleuroncodes planipes feces sample (Fig. 5d).

Fucoxanthinol is not reported to be among the reaction products of fucoxanthin in basic solutions (Bonnett et al. 1969, Repeta 1982). The products of fucoxanthin obtained from diagnostic laboratory reactions are concisely summarized by Liaaen-Jensen (1971). The absorption maxima and HPLC retention times of base reaction products of fucoxanthin are reported in Table $4 \mathrm{C}$. None of these corresponded to the retention time of the product in the Pleuroncodes planipes feces which had a fucoxanthin-like absorption spectrum (Fig. 7b, c, Table 4A).

Derivatives of $19^{\prime}$-hexanoyloxyfucoxanthin could differ significantly in their chromatographic properties from those of fucoxanthin, due to reactions involving the $19^{\prime}$-ester. Two major and 4 minor products were detected by HPLC analyses after treatment of $19^{\prime}$ hexanoyloxyfucoxanthin with base (Nelson 1986). The most polar of these compounds could be products in which both the $3^{\prime}$ - and $19^{\prime}$-esters were hydrolyzed. Absorption maxima for the 2 major products and 1 minor product are listed in Table 4D. From its absorption spectrum, and by analogy to the base hydrolysis products of fucoxanthin (Bonnett et al. 1969, Repeta 1982 ), it is possible that the major product at $4.4 \mathrm{~min}$ 
was $19^{\prime}$-hydroxyisofucoxanthinol. Little of the minor product at $5.1 \mathrm{~min}$ was recovered, but its absorption spectrum appears to be fucoxanthin-like (Table 4 ; Nelson 1986) suggesting that it could be $19^{\prime}$-hydroxyfucoxanthinol.

\section{DISCUSSION}

Comparison of the phytoplankton pigments in fecal material produced by 2 size classes of macrozooplankton grazers revealed distinct differences. The fecal material collected from copepod-dominated assemblages contained peridinin, fucoxanthin, and 19'-hexanoyloxyfucoxanthin, and there was no evidence that these ester-substituted xanthophylls were converted to their more polar hydroxyl derivatives in the guts of the animals (Fig. 3). In contrast, the pigment composition of fecal material produced by salps and by a pelagic crab was substantially altered from that of their presumed diet, the suspended particles of the euphotic zone. Several polar pigments in the salp and crab feces (Fig. 5) were not detected in either suspended particles or in the fecal material of the smaller grazers. The tentative identification of these pigments is discussed in the following section.

The difference in fecal pigment composition between the 2 size classes of grazers was consistent between stations and cruises, with one exception. Pigment analyses of Pleuroncodes planipes feces collected during a dinoflagellate bloom indicated that little alteration of carotenoids and chlorophylls had occurred within the guts of the crabs (Fig. 6). This observation is discussed further below, and may provide some insight into one of the sources of variability in fecal pigment composition.

\section{Nature of polar pigments in feces of larger grazers}

The identity of the polar peaks found in fecal pigment chromatograms for the larger grazers cannot be conclusively established with the available data. However, polar elution positions are expected for the hydroxyl derivatives of peridinin, fucoxanthin and 19'hexanoyloxyfucoxanthin, and the tentative identification of these products is supported by several observations.

First, in the salp fecal samples containing the unidentified polar peaks (Figs. 4c and 5b, c), very little fucoxanthin and $19^{\prime}$-hexanoyloxyfucoxanthin were present relative to their proportions in suspended particles from the euphotic zone (Figs. $4 \mathrm{a}, \mathrm{b}$, Table 2). The pigments in the suspended particles appeared to be dominated by those of living phytoplankton. Salps capture partic- les by pumping water through a mucus web filter, and in some species particles of $<1$ um diameter may be retained (Harbison \& Gilmer 1976, Harbison \& McAlister 1979). Thus, the filtered water samples should be representative of the pigments ingested by the salps, and the small amounts of fucoxanthin and 19'-hexanoyloxyfucoxanthin in the salp feces suggests that these pigments were degraded within the guts of the animals.

Confirmation that the polar pigments in the salp feces were carotenoids and not derivatives of the chlorophylls was provided by HPLC analyses with serial absorbance and fluorescence detection (Fig. 5a, b). With only a few exceptions, carotenoids are not fluorescent (Davies 1976). The fluorescence chromatograms contained no peaks corresponding to the elution positions of the polar peaks in the absorbance chromatograms (peaks ' $a$ ' and 'b' in Fig. 5). Although optimized for the detection of chlorophyll $a$ and its pheopigment derivatives, the fluorescence system should also have revealed the presence of significant quantities of pheopigments derived from other chlorophylls.

The most direct evidence relating to the identity of one of the polar carotenoid products was provided by the visible absorption spectra obtained for Pleuroncodes planipes fecal pigments separated by HPLC. The fucoxanthin-like absorption spectrum of one product (fraction ' $b$ ' in Fig. 7b, c, Table 4) matches the spectral properties of fucoxanthinol (Bonnett et al. 1969, Repeta 1982).

The presence of peridininol and $19^{\prime}$-hydroxyfucoxanthinol in the fecal samples from the larger grazers were not firmly established. Modification of peridinin by base hydrolysis resulted in the formation of a more polar product with the spectral properties of peridinin (Table 4B); consistent with peridininol (Johansen et al. 1974). The HPLC elution position of peridininol corresponded to that of one of the polar carotenoid products (peak 'a' in Fig. 5). One minor product resulting from base treatment of $19^{\prime}$-hexanoyloxyfucoxanthin had a fucoxanthin-like spectrum (Table $4 \mathrm{D}$ ). It is possible that this product was $19^{\prime}$-hydroxyfucoxanthinole. A mixture of peridininol and this hydrolyzed product of 19'hexanoyloxyfucoxanthin might account for the rather broad width of peak 'a' in the Salpa sp. feces sample (Fig. 5c)

Fig. 8 illustrates a chromatogram for Salpa sp. fecal pigments with tentative assignments for the polar carotenoid products, based on the above evidence. The hydrolysis products of peridinin and 19' -hexanoyloxyfucoxanthin may have been partially resolved in this sample. Several degradation products of the chlorophylls are also noted, designations based upon visible absorption spectra of collected fractions from 


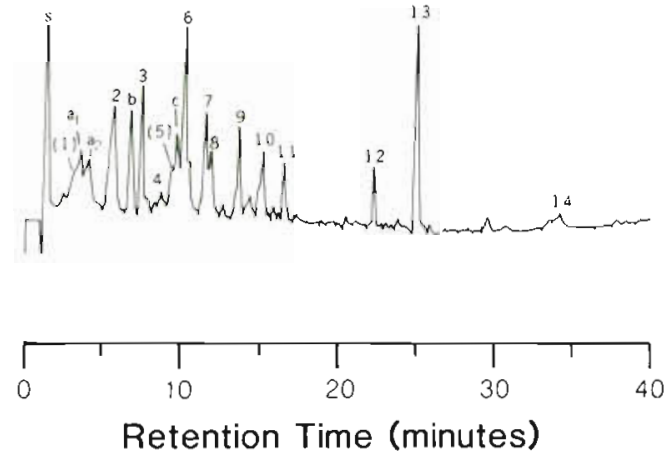

Fig. 8. HPLC chromatogram for fecal pigments from Salpa sp. Numbered peaks as for Fig. 3 . Lettered peaks: $a_{1}$, tentatively identified as peridinol; $a_{2}$ tentatively identified as $19^{\prime}$-hydroxyfucoxanthinol; b, fucoxanthinol; $c$, 'possibly pheophorbide' $c$

Pleuroncodes planipes feces, and HPLC analyses of products obtained by acidification of chlorophylls and chlorophyllide a (Nelson 1986). Note that in this sample fucoxanthin and $19^{\prime}$-hexanoyloxyfucoxanthin were present in significant amounts. Variability in the extent to which these pigments were apparently degraded in the guts of the larger grazers is discussed below.

\section{Other field studies of gut and fecal pigments}

The pigment composition of macrozooplankton fecal pellets and gut contents have been analysed by chromatographic methods in a number of other studies. In general, these observations also indicate that degradation of the ester-substituted carotenoids is associated with relatively large grazers. Repeta \& Gagosian (1984) reported a variable composition of fucoxanthin and its derivatives in fecal pellet samples collected in coastal waters off Peru. In the fecal pellets of the anchovetta, Engraulis ringens, fucoxanthinol constituted $49 \%$ and fucoxanthin $48 \%$ of the total 'fucopigments', while fecal pellets produced by mixed assemblages of crustaceans (reported to be euphausids and copepods) contained mostly intact fucoxanthin (50 to $80 \%)$ and considerably less fucoxanthinol ( 2 to $20 \%$ ). In other studies, chromatograms for copepod gut contents (Kleppel \& Pieper 1984) and copepod fecal pellets (Jeffrey 1974, Hallegraef 1981) show the presence of the major carotenoids, but no polar carotenoid derivatives, while a relatively polar carotenoid, reported to be a derivative of fucoxanthin, was detected in salp gut contents analysed by TLC (Hallegraef 1981, Madin \& Cetta 1984). The extent to which the ester-substituted carotenoids are altered in the guts of the larger grazers appears to vary however. Wright \& Shearer (1984) illustrated an HPLC chromatogram for the gut pigments of an Antarctic salp in which no polar carotenoid products are evident (fucoxanthin was the major carotenoid in that sample), and as previously noted, Pleuroncodes planipes feces collected during a dinoflagellate bloom showed little evidence of pigment degradation (Fig. 6).

\section{Possible mechanism of pigment alterations in the guts of grazers}

The differences in the fecal pigment composition between the 2 size classes of grazers could reflect differences in the chemical and/or enzymatic conditions within their guts. Gut $\mathrm{pH}$ is one factor that could play an important role in pigment alterations. However, indirect evidence indicates that the guts of macrozooplankton are not strongly acidic, and the apparent alterations of the ester-substituted carotenoids noted in the present study may result from gut esterase activity. rather than gut $\mathrm{pH}$.

Calcite coccoliths from the fecal pellets of copepods (Roth et al. 1975, Honjo \& Roman 1978), pteropods and salps (Silver \& Bruland 1981) were reported to show no evidence of dissolution, indicating that they had not been exposed to strongly acidic conditions within the guts of the animals. Several studies have determined $\mathrm{pH}$ optima in the range of 5.0 to 7.0 for the in vitro activity of gut carbohydrases from copepods (Mayzaud 1986), which could imply similar conditions within the guts of the animals. Neutral to moderately acidic gut conditions in marine zooplankton are also consistent with gut $\mathrm{pH}$ values determined for other marine invertebrates, which generally range from 5.0 to 7.0 for decapods (Gibson \& Barker 1979) and bivalves (Morton 1974).

From consideration of the products obtained from acid and base rearrangements of fucoxanthin in the laboratory, Repeta and Gagosian $(1982,1984)$ concluded that fucoxanthinol was formed in the guts of zooplankton by an enzymatic hydrolysis. From similar evidence, Galasko et al. (1969) had proposed an enzymatic mechanism for the formation of fucoxanthinol in the guts of sea urchins. When exposed to strong acid, the epoxide of fucoxanthin is converted to a furanoid oxide yielding a 'fucochrome' product rather than fucoxanthinol (Jensen 1963, Bonnett et al. 1969, Repeta 1982). The possible involvement of non-specific gut esterases in the formation of fucoxanthinol is suggested by the study of Jacobs et al. (1982), who reported the in vitro hydrolysis of several carotenoid esters, including that of fucoxanthin, by a sterol esterase.

An enzymatic mechanism for the formation of peridininol, fucoxanthinol, and 19'-hydroxyfucoxanthinol does not account for the absence of these products in the fecal material of smaller macrozooplank- 
ton. Several factors could contribute to the observed difference in carotenoid degradation between the two size classes of grazers, including differences in diet, in digestive enzymes, and in the transit time of ingested material through the guts of the animals.

The diets of the larger grazers are potentially quite general, with particle ingestion being primarily determined by the retention efficiency of their filtering structures. The fine mucus web filters of salps can retain very small particles (Harbison \& Gilmer 1976, Harbison \& McAlister 1979, Mullin 1983), thus the diet of salps may include bacteria as well as phytoplankton and small metazoans. The filter mesh of Pleuroncodes planipes is rather coarse by comparison (Boyd 1962), but can retain the larger protozoans (foraminifera and radiolarians), small planktonic metazoans, and the larger phytoplankton (Longhurst et al. 1976). Both salps and red crabs could also ingest organic aggregates and their associated microorganisms (Silver et al. 1979). On the other hand, copepods are potentially more selective in their diets. Studies employing microcinematography have revealed that some herbivorous copepods capture and manipulate individual phytoplankton cells above a certain size threshold (e.g. Price et al. 1983). It is conceivable that the range of gut enzymes is narrower or enzymes are more specific in herbivorous copepods than in the filter-feeding salps and crabs due to a more selective diet. Diet-induced differences in the digestive esterase activity of a harpactacoid copepod were reported by Guerin \& Kerambrun (1982).

Jacobs et al. (1982) found the in vitro hydrolysis rates of carotenoid esters by cholesterolase to be dependent upon both the carotenoid end ring structure and the ester substitution. Astaxanthin esters were cleaved at a higher rate than the acetate ester of fucoxanthin. Thus, the length of time the ester-substituted carotenoids are exposed to non-specific esterases in the guts of grazers could influence the extent to which they are converted to the corresponding alcohols.

While the residence time of material within the gut of any one species can be influenced by a number of factors, including temperature, food concentration and prior conditioning of the animals, it appears that gut transit time generally scales to the size of the animal. For various copepod species, estimates of gut clearance time range from $<0.5 \mathrm{~h}$ to $3.0 \mathrm{~h}$ (Marshall and Orr 1955 , Mackas \& Bohrer 1976, Dagg \& Grill 1980, Huntley et al. 1987). For 3 salp species, estimated gut clearance times were longer, ranging from 3 to $12 \mathrm{~h}$, with averages between about 3 and $5 \mathrm{~h}$ for individual experiments with Salpa maxima (Madin \& Cetta 1984). A rough estimate for the transit time of ingested material through the gut of Pleuroncodes planipes (derived from observations reported in Longhurst et al. 1967) is about $2 \mathrm{~h}$.
In the present study, the one exception to the pattern of more extensive pigment alterations in the fecal material of the larger grazers was for Pleuroncodes planipes collected during a dinoflagellate bloom. The HPLC chromatogram for the crab feces sample was dominated by the intact dinoflagellate pigments (Fig. 6 ). Given the extremely high concentrations of dinoflagellate cells at this time, the passage of ingested material through the guts of the crabs may have been quite rapid. Madin \& Cetta (1984) noted an inverse relationship between food concentration and gut clearance time in salps. Such an abundance of food might also have resulted in a lower concentration of gut enzymes. Nott et al. (1985) described a cycle of depletion and replenishment of enzyme-secreting digestive cells in the gut of a herbivorous copepod. Following a period of feeding, the pool of digestive cells became exhausted, and nearly intact chloroplasts from ingested phytoplankton were detected within the copepod gut.

Apparently intact bacteria have been noted within fresh fecal pellets of Pleuroncodes planipes (Gowing \& Silver 1983) and salps and pteropods (Silver \& Bruland 1981). However, on a time scale of hours to days, bacterial degradation of phytoplankton pigments may not be significant under most conditions. Slow or negligible degradation of pheopigments and chlorophylls contained in detrital particles incubated in darkness have been reported (Lorenzen 1967. Daley 1973, Welshmeyer \& Lorenzen 1985). Also, Nelson (1986) noted lttle change in the relative proportions of carotenoids, pheopigments, and chlorophylls in salp feces incubated in darkness for $40 \mathrm{~h}$ in unfiltered surface seawater (at $\sim 17^{\circ} \mathrm{C}$ ), indicating that bacteria did not mediate the conversion of the ester-substituted carotenoids to the polar carotenoid products found in the salp feces (Fig. 5b, c).

Unlike alterations of the ester-substituted carotenoids, the degradation of chlorophyll a to pheopigments occurs in the guts of both large and small macrozooplankton. Even weakly acidic conditions appear to be sufficient for removal of the magnesium from chlorophyll a. However, the usual product resulting from acidification of chlorophyll $a$ in solution is pheophytin $a_{\text {, }}$ while the dephytolated product, pheophorbide $a$, has often been reported to be the principal pheopigment in zooplankton fecal pellets (e.g Shuman \& Lorenzen 1975). Pheophytin a is converted to pheophorbide a by strong acid (French 1960), but in the range of $\mathrm{pH}$ indicated for the guts of macrozooplankton, the phytol ester may remain intact, or be hydrolyzed at a very slow rate (Daley \& Brown 1973).

Esterases in the guts of both size classes of macrozooplankton could catalyze the dephytolization reaction. The best known example of an enzymatic hydrolysis of the phytol ester is through the in vitro activity of an 
algal enzyme, chlorophyllase (Barrett \& Jeffrey 1964, 1971, Owens \& Falkowski 1982, Suzuki \& Fujita 1986). The presence of a specific phytol esterase in the guts of zooplankton has not been established, but the assimilation and metabolic conversion of phytol to pristane by copepods has been demonstrated (Avigan \& Blumer 1968, Prahl et al. 1984a). Phytol has also been detected in copepod fecal pellets produced in laboratory experiments (Prahl et al. 1984a, 1984b), indicating that its assimilation by copepods can be incomplete (although high phytoplankton concentrations in those experiments may have contributed to low assimilation efficiency). Variable activity of phytol esterases in the guts of grazers related to food concentrations and gut transit time might account for temporal variation of pheopigment composition in fecal pellets and sedimenting particles observed in field studies (Bathmann \& Liebezeit 1986, Vernet \& Lorenzen 1987).

\section{Relationships between fecal pigments and pigments ingested by grazers}

Fox (1960) summarized the possible fates of carotenoids ingested by animals as: (1) discharged in feces without alteration; (2) assimilated and stored in an unaltered form; (3) assimilated and converted into other carotenoids; (4) assimilated and oxidatively consumed or otherwise converted into colorless substances; (5) destroyed in the gut (i.e. converted to colorless substances). The results of the present study illustrate 2 possible fates; incorporation of the intact carotenoids into fecal pellets, and incorporation into feces after structural alteration, but with the chromophore intact (an alternative which could be added to Fox's list). The other possibilities, that ingested carotenoids are assimilated or converted to colorless products, cannot be adequately evaluated with the available data.

However, assimilation of peridinin, fucoxanthin, and $19^{\prime}$-hexanoyloxyfucoxanthin by macrozooplankton for conversion into animal carotenoids seems unlikely While animal carotenoids must be derived from dietary sources, their metabolic alterations are generally by oxidative pathways (Goodwin 1984). Conversion of fucoxanthin and $19^{\prime}$-hexanoyloxyfucoxanthin to the major carotenoids of copepods, astaxanthin and astaxanthin esters (Fisher et al. 1964), would require reductive pathways that have not been demonstrated. Furthermore, peridinin lacks a 3-carbon unit from the polyene chain of the molecule, making it unsuitable as a precursor for astaxanthin.

The potential degradation of phytoplankton pigments to colorless products in the guts of grazers may be the most critical factor determining whether carotenoids and pheopigments in fecal material and gut contents can be quantitatively related to the pigments ingested by animals. Repeta \& Gagosian (1984) concluded that up to $80 \%$ of the carotenoids ingested by zooplankton (primarily fucoxanthin in their samples from coastal Peru) were degraded to colorless products in the guts of the animals, based on comparison of the ratio of 'total carotenoids' to 'total chlorins' in suspended particles versus zooplankton feces. The carotenoid:chlorin ratio was considerably lower in the fecal samples, which they interpreted as preferential assimilation or degradation of carotenoids. The results of the present study do not appear to be consistent with their conclusion. Comparison of fecal pigment chromatograms with chromatograms for suspended particles (see Figs. 3 and 4) does not indicate a great enrichment of chlorins (chlorophylls plus pheopigments) relative to carotenoids in fecal material, particularly for the salp feces (Fig. 5b, c). In part, these contradictory results and conclusions may be due to methodological differences. Repeta \& Gagosian (1984) determined total pigment fractions by size exclusion chromatography, rather than by HPLC.

Several pigment-based approaches used in quantitative studies of trophic relationships are critically dependent upon the fate of pigments ingested by grazers. Gut pigment content has been used to estimate ingestion rates of herbivorous zooplankton in the field (e.g. Mackas \& Bohrer 1976, Madin \& Cetta 1984) and to assess the preference of grazers for different phytoplankton taxa (Kleppel \& Pieper 1984). The carbon assimilation efficiency of zooplankton has been estimated from pheopigment:carbon ratios in fecal pellets (Downs \& Lorenzen 1985), and the pigment budget model of Welshmeyer \& Lorenzen (1985) examined the relationship between pelagic food web dynamics and particle flux. Each of these approaches assumes that pigment chromophores are not significantly degraded to colorless products within the guts of grazers. This assumption appeared to be justified in view of Shuman \& Lorenzen's (1975) report of a stoichiometric relationship between the pheopigment content of fecal pellets and the chlorophyll $a$ ingested by several copepod species. However, Shuman \& Lorenzen's conclusions have recently been challenged (see Conover et al. 1986, Kiorboe \& Teselius 1987), and degradation of both chlorophyll a and carotenoids to colorless products by a protozoan grazer has been reported (Klein et al. 1986).

The question of whether carotenoid and chlorophyl chromophores are conserved during passage through the guts of macrozooplankton requires further study in controlled grazing experiments. In such experiments, potential sources of variability in fecal pigment composition should be carefully considered. The results of the present study indicate that both the food concentrations available to grazers and the species composi- 
tion of the zooplankton assemblage can influence the pigment content of macrozooplankton feces. More detailed information on the mechanisms of pigment alterations in the guts of various macrozooplankton would also contribute to a better understanding of how fecal pigment composition varies between species and with the physiological condition of grazers.

\section{Relationships between iecal pigments and pigment composition of sedimenting particles}

The hydrolyzed derivatives of peridinin, fucoxanthin, and 19 ' -hexanoyloxyfucoxanthin may be organic 'markers' for the fast sinking feces egested by larger grazers. A significant contribution of large fecal particles to the total flux measured by sediment traps has been noted when anchovetta (Staresinic et al. 1982, Repeta \& Gagosian 1984), Pleuroncodes planipes (Wakeham \& Canuel 1986. Nelson et al. 1987), and the larger salp species (Wiebe et al. 1979, Iseki 1981) are abundant in surface waters. Patchy distribution of such large grazers can strongly influence the pigment 'signal' in sedimenting particles (Nelson 1986). Potentially, the pigment content of sedimenting particles could provide a means of assessing relationships between phytoplankton production in the euphotic zone and biologically-mediated transformations of organic matter within the water column.

Acknowledgements. I am grateful for the guidance and support provided by R.W. Eppley. The resources of the Food Chain Research Group were utilized throughout the study, and, in particular, P. M. Williams, A. F. Carlucci, G. A. Jackson, K. Robertson, T. J. Jacobsen, E. Brooks, B. Balch and J. M. Napp are thanked for their help. F. T Haxo and M. M. Mullin provided valuable input to the thesis of which this study is part. D. Peterson assisted in the preparation of the manuscript and A. Boyette drafted figures. The comments of three reviewers are appreciated. This work was supported by U.S. Department of Energy Contracts DE-AT03-82-ER60031 and DEF605-85-ER60336 and NSF grants OCE-84-16320 and OCE86-13685 (to R. W. Eppley).

\section{NOTE ADDED IN PROOF}

Two recently published studies present data which are pertinent to the question of the fate of phytoplankton pigments ingested by macrozooplankton. Results of grazing studies conducted by Pasternak \& Drits (1988, Mar. Ecol. Prog. Ser. 49: 187-190) indicate that the sum of chlorophyll and its pheopigment derivatives is largely conserved during passage through the guts of 3 copepod species. Details of pigment composition were not reported. Kleppel et al. (1988, Mar. Ecol. Prog. Ser. 49: 231-241) report intact phytoplankton carotenoids within the guts of copepods and a cladoceran.

\section{LITERATURE CITED}

Arpin, R., Svec, W. A., Liaaen-Jensen, S. (1976). New fucoxanthin-related carotenoids from Coccolithus huxleyi. Phytochemistry 15: 529-532

Avigan, J., Blumer, M. (1968). On the origin of pristane in marine organisms. J. Lipid Res. 9: 350-352

Bathmann, U., Liebezeit, G. (1986). Chlorophyll in copepod faecal pellets: changes in pellet numbers and pigment content during a declining Baltic spring bloom. P.S.Z.N.I. Mar Ecol. 7: 59-73

Barrett, J., Jeffrey, S. W. (1964). Chlorophyllase and formation of an atypical chlorophyllide in marine algae. Plant Physiol. 39: 44-47

Barrett, J., Jeffrey, S. W. (1971). A note on the occurrence of chlorophyllase in marine algae. J. exp. mar. Biol. Ecol. 7: $255-262$

Bienfang, P. K. (1981). Sinking rates of heterogeneous, temperate phytoplankton populations. J. Plankton Res. 3: 235-253

Bonnett, R., Mallams, A. K., Spark, A. A., Tee, J. L., Weedon, B. C. L., McCormick, A. (1969). Carotenoids and related compounds. Part XX. Structure and reactions of fucoxanthin. J. Chem. Soc. (C) 1969: 429-454

Boyd, C. M. (1962). The biology of a marine decapod crustacean, Pleuroncodes planipes Stimpson, 1860. Ph. D. thesis, University of California, San Diego

Conover, R. J., Durvasula, R., Roy, S, Wang, R. (1986). Probable loss of chlorophyll-derived pigments during passage through the gut of zooplankton, and some of the consequences. Limnol. Oceanogr. 31: 878-887

Dagg, M. J., Grill, D. W. (1980). Natural feeding rates of Centropages typicus females in the New York Bight. Limnol. Oceanogr 25: 597-609

Daley, R. J. (1973). Experimental characterization of lacustrine chlorophyll diagenesis. II. Bacterial, viral, and herbivore grazing effects. Axch. Hydrobiol. 72: 409-439

Daley, R. J., Brown, S. R. (1973). Experimental characterization of lacustrine chlorophyll diagenesis. I. Physiological and environmental effects. Arch. Hydrobiol. 72: 277-304

Davies, B. H. (1976). Carotenoids. In: Goodwin, T. W (ed.) Chemistry and biochemistry of plant pigments, 2nd edn, Vol. 2. Academic Press, New York, p. 38-165

Downs, J. N., Lorenzen, C. J. (1985). Carbon:pheopigment ratios of zooplankton fecal pellets as an index of herbivorous feeding. Limnol. Oceanogr. 30: 1024-1036

Eppley, R. W., Harrison, W G., Chisholm, S. W., Stuart, E. (1977). Particulate organic matter in surface waters off Southern California and its relationship to phytoplankton. J. mar. Res. 35: 671-696

Eppley, R. W., Holmes, R. W., Strickland, J. D. H. (1967) Sinking rates of phytoplankton measured with a fluorometer. J. exp. mar. Biol. Ecol. 1: 191-208

Eppley, R. W., Sapienza, C., Renger, E. H. (1978). Gradients in phytoplankton stocks off Southern California in 1974-76. Estuar. coast. mar. Sci. 7: 291-301

Fisher, L. R., Don, S. K., Thompson, S. Y (1964). Vitamin A and carotenoids in certain invertebrates. VIII Crustacea: Copepoda. J. mar. biol. Ass. U. K. 44: 685-692

Fowler, S. W., Knauer, G. A. (1986). Role of large particles in the transport of elements and organic compounds through the oceanic water column. Prog. Oceanogr 16: 147-194

Fox, D. L. (1960). Pigments of plant origin in animal phyla. In: Allen, M. B (ed.) Comparative biochemistry of photoreactive systems. Academic Press, New York, p. 11-31

French, C. S. (1960). The chlorophylls in vivo and in vitro. In: Ruhland, W. (ed.) Encyclopedia of plant physiology, Vol. V, Part 1. Springer-Verlag, Berlin, p. 252-297 
Galasko, G., Hora, J., Toube, T P., Weedon, B. C. L., Andre, D., Barbier, M., Lederer, E., Villanueva, V R. (1969). Carotenoids and related compounds. Part XXII. Allenic carotenoids in sea urchins. J. Chem. Soc. (C) 1969: $1264-1265$

Gibson, R., Barker, P. L. (1979). The decapod hepatopancreas. Oceanogr. mar Biol. A. Rev. 17: 285-346

Gieskes, W W., Kraay, G. W (1986). Analysis of phytoplankton pigments by HPLC before, during and after mass occurrence of the microflagellate Corymbellus aureus during the spring bloom in the open northern North Sea in 1983. Mar Biol. 92: 45-52

Goodwin, T W. (1971). Algal carotenoids. In: Goodwin, T W (ed.) Aspects of terpenoid chemistry and biochemistry. Academic Press, London, p. 315-356

Goodwin, T W. (1984). The biochemistry of the carotenoids Vol, II. Animals. Chapman and Hall, London

Gowing, M. M., Silver, M. W. (1983). Origins and microenvironments of bacteria mediating fecal pellet decomposition in the sea. Mar Biol. 73: 7-16

Guerin, J. P., Kerambrun, P. (1982). Effects of diet on esterases, alkaline phosphatase, malate dehydrogenase and phosphoglucomutase activity observed by polyacrylamide gel electrophoresis in Tisbe holothuriae (harpactacoid copepod). Comp. Biochem. Physiol. 73B: 761-770

Hallegraef, G. M. (1981). Seasonal study of phytoplankton pigments and species at a coastal station off Sydney: importance of diatoms and the nanoplankton. Mar Biol. 61: $107-118$

Harbison, C. R., Gilmer, R. W. (1976). The feeding rates of the pelagic tunicate Pegea confederata and two other salps. Limnol. Oceanogr. 21: 517-528

Harbison, G. R., McAlister, V. L. (1979). The filter-feeding rates and particle retention efficiencies of three species of Cyclosalpa (Tunicata, Thaliacea). Limnol. Oceanogr 24 875-892

Haxo, F. T (1985). Photosynthetic action spectrum of the coccolithophorid, Emiliania huxleyi (Haptophyceae): 19'hexanoyloxyfucoxanthin as antenna pigment. J. Phycol. $21 \quad 282-287$

Honjo, S., Roman, M. R. (1978). Marine copepod fecal pellets: production, preservation and sedimentation. J. mar. Res. 36: $45-57$

Huntley, M. E., Marin, V., Escritor, F. (1987). Zooplankton grazers as transformers of ocean optics: a dynamic model. J. mar. Res. 45: 911-945

Iseki, K. (1981). Particulate organic matter transport to the deep sea by salp fecal pellets. Mar. Ecol. Prog. Ser. 5 $55-60$

Jacobs, P. B., LeBoeuf, R. D., McCommas, S. A., Tauber, J. D (1982). The cleavage of carotenoid esters by cholesterol esterase. Comp. Biochem. Physiol. 72B: 157-160

Jeffrey, S. W. (1974). Profiles of photosynthetic pigments in the ocean using thin-layer chromatography. Mar. Biol. 26: 101-110

Jeffrey, S. W. (1980). Algal pigment systems. In: Falkowski, P. G. (ed.) Primary productivity in the sea. Plenum, New York, p. 33-58

Jeffrey, S. W. (1981). An improved thin-layer chromatographic technique for marine phytoplankton pigments. Limnol. Oceanogr. 26: 191-197

Jeffrey, S. W., Humphrey, G. F. (1975). New spectrophotometric equations for determining chlorophylls $a, b, c_{1}$, and $c_{2}$ in higher plants, algae and natural phytoplankton. Biochem. Physiol. Pflanz. 167: 191-194

Jensen, A. (1963). The effect of seaweed carotenoids on egg yolk coloration. Poult. Sci. 42: 912-916
Jensen, A. (1973). Chlorophylls and carotenoids. In: Hellebust, J. A., Craigie, J. S. (eds.) Handbook of phycological methods: physiological and biochemical methods. Cambridge University Press, Cambridge, p. 59-71

Johansen, J. E., Svec, W. A., Liaaen-Jensen, S., Haxo, F. T. (1974). Carotenoids of the Dinophyceae. Phytochemistry 13: 2261-2271

Klein, B., Gieskes, W. W. C., Kraay, G. G. (1986). Digestion of chlorophylls and carotenoids by the marine protozoan Oxyrrhis marina studied by h.p.l.c. analysis of algal pigments. J. Plankton Res. 8: 827-836

Kleppel, G. S., Pieper, R. E. (1984). Phytoplankton pigments in the gut contents of planktonic copepods from coastal waters off southern California. Mar. Biol. 78: 193-198

Kiorboe, T., Teselius, P. T. (1987). Gut clearance and pigment destruction in a herbivorous copepod, Acartia tonsa, and the determination of in situ grazing rates. J. Plankton Res. 9: $525-534$

Liaaen-Jensen, S. (1971). Recent progress in carotenoid chemistry. In: Goodwin, T. W. (ed.) Aspects of terpenoid chemistry and biochemistry. Academic Press, London, p. 223-254

Longhurst, A. R, Lorenzen, C. J., Thomas, W. H. (1967). The role of pelagic crabs in the grazing of phytoplankton off Baja California. Ecology 48: 190-200

Lorenzen, C. J. (1967). Vertical distribution of chlorophyll and phaeo-pigments: Baja California. Deep Sea Res. 14: 735-745

Mackas, D., Bohrer, R. (1976). Fluorescence analysis of zooplankton gut contents and an investigation of diel feeding patterns. J. exp. mar Biol. Ecol. 25: 77-85

Madin, L. P., Cetta, C. M. (1984). The use of gut fluorescence to estimate grazing by oceanic salps. J. Plankton Res. 6 : 475-492

Mantoura, R. F. C., Llewellyn, C. A. (1983). The rapid determination of algal chlorophyll and carotenoid pigments and their breakdown products in natural waters by reversephase high-performance liquid chromatography. Analytica chim. Acta 151: 297-314

Marshall, S. M., Orr, A. P. (1955). The biology of a marine copepod. Oliver and Boyd, London. (Reprint, SpringerVerlag, Berlin (1972), 195 p.]

Mayzaud, P. (1986). Digestive enzymes and their relation to nutrition. In: Corner, E. D. S., O'Hara, S. C. M. (eds.) The biological chemistry of marine copepods. Clarendon Press, Oxford, p. 165-225

Morton, B. (1974). Feeding and digestion in Bivalvia. In: Saleuddin, A.S. M., Wilbur, K. M. (eds.) The Mollusca, Vol. 5, Physiology, Part 2. Academic Press, New York, p. 65-147

Mullin, M. M. (1983). In situ filtering rates of the salp, Thalia democratica, on phytoplankton and bacteria. J. Plankton Res. 5: 279-288

Nelson, J. R. (1986). Phytoplankton carotenoids as organic tracers in marine particulate organic matter. Ph. D. thesis, University of California, San Diego

Nelson, J. R., Beers, J. R., Eppley, R. W., Jackson, G. A., McCarthy, J. J., Soutar, A. (1987). A particle flux study in the Santa Monica-San Pedro Basin off Los Angeles: particle flux, primary production, and transmissometer survey. Cont. Shelf. Res. 7: 307-328

Nott, J. A., Corner, E. D. S., Mavin, L. J., O'Hara, S. C. M. (1985). Cyclical contribution of the digestive epithelium to faecal pellet formation by the copepod Calanus helgolandicus. Mar Biol. 89: 271-279

Owens, T G., Falkowski, P. G. (1982). Enzymatic degradation of chlorophyll a by marine phytoplankton in vitro. Phytochemistry $21 \quad 979-984$ 
Prahl, F. G., Eglinton, G., Corner, E. D. S., O'Hara, S. C. M. (1984a). Copepod fecal pellets as a source of dihydrophytol in marine sediments. Science 224: 1235-1237

Prahl, F. G., Eglinton, G., Corner, E. D. S., O'Hara, S. C. M. Forsberg, T E. V (1984b). Changes in plant lipids during passage through the gut of Calanus. J. mar. biol. Ass. U. K. 64: $317-334$

Price, H. J., Paffenhöfer, G.-A., Strickler, J. R. (1983). Modes of cell capture in calanoid copepods. Limnol. Oceanogr. 28: $116-123$

Repeta, D. J. (1982). Transformations of carotenoids in the oceanic water column. Ph. D. thesis, Massachusetts Institute of Technology-Woods Hole Oceanographic Institution

Repeta, D. J., Gagosian, R. B. (1982). Carotenoid transformations in coastal marine waters. Nature, Lond. 295: 51-54

Repeta, D. J., Gagosian, R. B. (1984). Transformation reactions and recycling of carotenoids and chlorins in the Peru upwelling region $\left(15^{\circ} \mathrm{S}, 75^{\circ} \mathrm{W}\right)$. Geochim. Cosmochim. Acta 48: $1265-1277$

Roth, P. H., Mullin, M. M., Berger, W H. (1975). Coccolith sedimentation by fecal pellets: laboratory experiments and field observations. Geol. Soc. Am. Bull. 86: 1079-1084

Shuman, F. R., Lorenzen, C. J. (1975). Quantitative degradation of chlorophyll by a marine herbivore. Limnol. Oceanogr 20: $580-586$

Silver, M. W., Bruland, K. W (1981). Differential feeding and fecal pellet composition of salps and pteropods, and the possible origin of deep-water flora and the olive-green 'cells'. Mar Biol. 62: 263-273

Silver, M. W., Shanks, A. L., Trent, J. D. (1978). Marine snow: microplankton habitat and source of small-scale patchiness in pelagic populations. Science 201.371-373

Small, L. F., Fowler, S. W. Unlu, M. Y (1979). Sinking rates of natural copepod fecal pellets. Mar. Biol. 51. 233-241

Smayda, T. J. (1970). The suspension and sinking of phyto-

This article was presented by Professor G.-A. Paffenhöter, Savannah, Georgia, USA plankton in the sea. Oceanogr. mar. Biol. A. Rev. 8: $353-414$

Staresinic, N., Farrington, J. W., Gagosian, R. B., Clifford, C. H., Huburt, E. M. (1982). Downward transport of particulate matter in the Peru coastal upwelling: role of the anchovetta, Engraulis ringens. In: Suess, E., Thiede, J. (eds.) Coastal upwelling, its sedimentary record. Plenum, Press, New York, p. 225-240

Suzuki, R., Fujita, Y. (1986). Chlorophyll decomposition in Skeletonema costatum: a problem in chlorophyll determination of water samples. Mar. Ecol. Prog. Ser. 28: 81-85

Triebs, A. (1936). Chlorophyll and hemin derivatives in organic mineral substances (a review). Angew. Chem. 49: $682-686$

Vernet, M., Lorenzen, C. J. (1987). The relative abundance of pheophorbide a and pheophytin a in temperate marine waters. Limnol. Oceanogr 32: 352-358

Wakeham, S. G., Canuel, E. A. (1986). Lipid composition of the pelagic crab Pleuroncodes planipes, its feces, and sinking particulate organic matter in the Equatorial North Pacific Ocean. Org. Geochem. 9: 331-343

Welshmeyer, N. A., Lorenzen, C. J. (1985). Chlorophyll budgets: zooplankton grazing and phytoplankton growth in a temperate fjord and the Central Pacific Gyre. Limnol. Oceanogr. 30: 1-21

Wiebe, P. H., Madin, L. P., Haury, L. R., Harbison, G. R., Philbin, L. M. (1979). Diel vertical migration by Salpa aspera and its potential for large-scale particulate organic matter transport to the deep sea. Mar. Biol. 53: 249-255

Wright, S. W., Jeffrey, S. W. (1987). Fucoxanthin pigment markers of marine phytoplankton analysed by HPLC and HPTLC. Mar. Ecol. Prog. Ser. 38: 259-266

Wright, S. W., Shearer, J. D. (1984). Rapid extraction and highperformance liquid chromatography of chlorophylls and carotenoids from marine phytoplankton. J. Chromatogr. 294: $281-295$

Manuscript received: July 14, 1988

Revised version accepted: December 15, 1988 